\title{
Qualitative and quantitative identification of adulteration of milk powder using DNA extracted with a novel method
}

\author{
J. Liao, Y. F. Liu, ${ }^{1}$ T. Ku, M. H. Liu, and Y. Huang \\ College of Food Engineering and Nutritional Science, Shaanxi Normal University, Xi'an, 710062, Shaanxi, China
}

\begin{abstract}
The extraction of high-quality DNA from processed dairy products is often the crucial step in an authentication process by PCR-based methods. In this study, we optimized a novel DNA extraction method for milk powder and used the extracted DNA for identification of milk powder based on PCR analysis. The DNA quality was assessed by amplifying target sequences from mitochondrial genes, as well as by monitoring the yield, purity, and integrity of the extracted DNA. In addition, a laboratory adulteration model of milk powder was detected by PCR-based methods (PCR and real-time PCR) using primers targeting the mitochondrial $12 \mathrm{~S}$ rRNA gene. Results showed that a sufficient amount and quality of DNA could be isolated from milk powder with this method. Both PCR and real-time PCR detection of cow milk compositions in goat milk powder further confirmed the DNA extracted with this extraction method could be widely used in addressing milk powder adulterant by a PCR-based method.
\end{abstract}

Key words: milk powder, DNA extraction, adulteration, PCR, DNA detection

\section{INTRODUCTION}

In recent years, goat milk powder has been preferred by consumers over cow milk powder because it has superior mineral composition, bioavailability, digestibility, and biological value (Raynal-Ljutovac et al., 2008). With increasing demand for goat milk powder, substitution or adulteration of goat milk powder with cow milk powder has been frequently reported. Adulteration is economically viable because cow milk powder costs less and is more available than goat milk in many countries (Zachar et al., 2011). Each year in China, 16 to 18 million babies are born and 300,000 t of milk powder is consumed (Liu et al., 2012); thus, the authenticity of milk powder is a major issue in China

Received August 22, 2016.

Accepted November 16, 2016.

${ }^{1}$ Corresponding author: yongfeng200@126.com and has been a concern of government authorities for decades. To avoid the possible fraudulent substitution of goat milk powder with cow milk, it is necessary to develop analytical procedures able to detect such fraud and protect consumers from misleading labels.

Existing methods for identification such as immunological, electrophoretic, and chromatographic methods (Enne et al., 2005; Mayer, 2005; López-Calleja et al., 2007) usually use lipids and proteins as a target analytes. These methods had been successfully applied to dairy products identification and played a significant role in the food industry, but they may not be practical for products containing lipids and proteins as target analytes because of their poor stability under high temperatures or pressures and chemical treatments during the processing of food products. More recently, DNA molecules have received much attention and been the target compounds for species identification based on PCR because they are thermally more stable than lipids and proteins. Therefore, PCR-based methods have been designed and applied to dairy products for authenticating goat milk, and these methods can detect very small amounts of cow milk in goat milk (Kotowicz et al., 2007; Hutu et al., 2013). Conventional PCR, however, cannot be used as an accurate quantitative tool for milk adulteration; thus, attempts to use real-time PCR as a quantitative tool for dairy products authentication are increasing, and the method has been applied to exclude the false positive of conventional $\mathrm{PCR}$, to reduce contamination rates, and to improve the reliability of results (Madani et al., 2005). So far, real-time PCR assays have been proposed to detect and quantify bovine milk in cheese (Lopparelli et al., 2007; Mininni et al., 2009) and in goat milk (Jung et al., 2011). These studies showed that PCR-based methods have a potential in addressing food adulteration.

A successful PCR assay depends largely on the quality of extracted DNA; thus, extraction of high-quality DNA has been a crucial step in the authentication process. Numerous DNA extraction methods have been used for the preparation of DNA from milk, including research protocols and commercial kits (Liu et al., 2014; Volk et al., 2014; Pokorska et al., 2016), but the 
DNA extraction method for milk powder is still poorly defined. As adulteration of milk powder increases, it is necessary to develop an effective DNA extraction method suitable for PCR-based investigations of milk powder. The aim of our study was to develop a new and effective DNA extraction method for milk powder. In addition, both conventional PCR and real-time PCR were carried out for detecting adulteration of cow milk in commercial goat milk powders.

\section{MATERIALS AND METHODS}

\section{Samples}

Whole milk powder was sourced from a local supermarket and their species were authenticated by subjecting the samples to species typing through a PCR-based approach.

\section{DNA Extraction and Quality Evaluation}

DNA Extraction Method of Milk Powder. To separate milk fat and other impurities, $1 \mathrm{~g}$ of milk powder was washed with $9 \mathrm{~mL}$ of purified water and centrifuged for $15 \mathrm{~min}$ at $4,150 \times g$ at $4^{\circ} \mathrm{C}$. The top layer and middle layer were removed, leaving the bottom sediment, which was washed twice with $600 \mu \mathrm{L}$ of PBS (pH 7.4, $4.8 \mu \mathrm{g}$ of $\mathrm{NaCl}, 0.12 \mu \mathrm{g}$ of $\mathrm{KCl}, 0.864$ $\mu \mathrm{g}$ of $\mathrm{Na}_{2} \mathrm{HPO}_{4}, 0.144 \mu \mathrm{g}$ of $\mathrm{KH}_{2} \mathrm{PO}_{4}$, and $600 \mu \mathrm{L}$ of double-distilled $\mathrm{H}_{2} \mathrm{O}$ ) before being centrifuged for 10 min at $10,625 \times g$ at $4^{\circ} \mathrm{C}$ in a $1.5-\mathrm{mL}$ centrifuge tube. After the washing stage, the sediment was mixed with $350 \mu \mathrm{L}$ of extraction buffer $(\mathrm{pH} 8.0,100 \mathrm{mM}$ Tris $\mathrm{Cl}$, $100 \mathrm{~m} M \mathrm{NaCl}$, and $5 \mathrm{mM}$ EDTA), $50 \mu \mathrm{L}$ of $20 \%$ (wt/ vol) SDS, and $10 \mu \mathrm{L}$ of proteinase $\mathrm{K}(20 \mathrm{mg} / \mathrm{mL})$. These mixtures were then incubated at $56^{\circ} \mathrm{C}$ for $4 \mathrm{~h}$ before an equal volume of Tris-phenol was added to the digested cell concentrate followed by vortex mixer for 1 min at 1,600 rpm. The mixture was centrifuged for 10 $\min$ at $10,625 \times g$ at $4^{\circ} \mathrm{C}$ to obtain supernatant. The supernatant was extracted once with an equal volume of phenol:chloroform:isoamyl alcohol (ratio of 25:24:1) and twice with an equal volume of chloroform:isoamyl alcohol (ratio of 24:1), followed by spinning in the vortex mixer for $1 \mathrm{~min}$ at 1,600 rpm before being centrifuged for $10 \mathrm{~min}$ at $10,625 \times \mathrm{g}$ at $4^{\circ} \mathrm{C}$ in a $1.5-\mathrm{mL}$ centrifuge tube to obtain the supernatant. Finally, DNA was precipitated with ice-cold absolute ethanol and washed once with ethanol:water (ratio of 7:3). Twenty-five microliters of Tris-EDTA $(\mathrm{pH}=8.0,1 \mathrm{~m} M$ Tris- $\mathrm{Cl}$ and $0.5 \mathrm{~m} M$ EDTA) was added to dissolve DNA.

Evaluation of DNA Quality. The concentration and purity of total DNA were controlled by absorbance readings at 260 and $280 \mathrm{~nm}$ using the Nanodrop ND1000 Spectrophotometer (Thermo Fisher Scientific Inc., Waltham, MA). The DNA integrity was detected with $1 \%$ agarose gel electrophoresis at $100 \mathrm{~V}$ for 40 min. After electrophoresis, the gel was observed under UV light imaging analyzer. In addition, the bovine $C y t b$ gene and ovine ATP 6 gene (Table 1) were amplified by PCR to verify the presence of amplifiable mitochondrial DNA in all isolates. The PCR reactions of Cytb (ATP6) were performed under following thermal cycling conditions: initial denaturation at $95^{\circ} \mathrm{C}$ for 10 min followed by 30 cycles of $94^{\circ} \mathrm{C}$ for $30 \mathrm{~s}, 60^{\circ} \mathrm{C}\left(62^{\circ} \mathrm{C}\right)$ annealing for $30 \mathrm{~s}, 72^{\circ} \mathrm{C}$ for $30 \mathrm{~s}$, and a final extension at $72^{\circ} \mathrm{C}$ for $10 \mathrm{~min}$. Both of the Cytb and ATP 6 amplification reactions were carried out in a mixture $(20 \mu \mathrm{L})$ comprising $6.8 \mu \mathrm{L}$ of TaqMan Universal PCR Master Mixture (CWBIO, Shanghai, China), $0.6 \mu \mathrm{L}(0.3 \mu M)$ of each primer, and $2 \mu \mathrm{L}$ of the template DNA; DNase/ DNA-free water (CWBIO) was added to the reactions up to $20 \mu \mathrm{L}$. The PCR products were detected with $1 \%$ agarose gel electrophoresis at $100 \mathrm{~V}$ for $40 \mathrm{~min}$ and photographed under UV light.

\section{Qualitative Detection of Cow Milk in Goat Milk Powders}

Cow-specific primer 12SBT-REV (Table 1) was selected for detection cow milk in goat milk powder by amplifying a 346-bp fragment in the $12 \mathrm{~S}$ rRNA gene. The spiked model was prepared by admixtures compromising $0.1,0.5,1,5,10,30$, and $50 \%$ (wt/wt) cow milk powder in goat milk powder, with each sample repeated 3 times. The DNA was isolated from these mixtures by

Table 1. Sequences of the primers

\begin{tabular}{|c|c|c|}
\hline Gene & Primer sequence $\left(5^{\prime}\right.$ to $\left.3^{\prime}\right)$ & $\begin{array}{l}\text { Fragment length } \\
\quad(\mathrm{bp})\end{array}$ \\
\hline$\overline{C y t b}$ & $\begin{array}{l}\text { Forward: CGACCTTCCAGCCCCATCGA } \\
\text { Reverse: AGCCGTAGTTCACGTCTCGGC }\end{array}$ & 173 \\
\hline ATP6 & $\begin{array}{l}\text { Forward: TATTAGGCCTCCCCCTTGTT } \\
\text { Reverse: CCCTGCTCATAAGGGAATAGCCC }\end{array}$ & 294 \\
\hline $12 S B T-R E V^{1}$ & $\begin{array}{l}\text { Forward: CTAGAGGAGCCTGTTCTATAATCGATAA } \\
\text { Reverse: AAATAGGGTTAGATGCACTGAATCCAT }\end{array}$ & 346 \\
\hline
\end{tabular}

${ }^{1}$ Primer sequences adopted from López-Calleja et al. (2005). 
a method we developed for PCR detection. The PCR reaction was carried out under the following thermal cycling conditions: initial denaturation at $95^{\circ} \mathrm{C}$ for 10 min, followed by 30 cycles of $94^{\circ} \mathrm{C}$ for $30 \mathrm{~s}, 60^{\circ} \mathrm{C}$ annealing for $30 \mathrm{~s}, 72^{\circ} \mathrm{C}$ for $30 \mathrm{~s}$, and a final extension at $72^{\circ} \mathrm{C}$ for $10 \mathrm{~min}$. The PCR amplification was performed in a $20-\mu \mathrm{L}$ reaction volume containing $6.8 \mu \mathrm{L}$ of TaqMan Universal PCR Master Mixture (CWBIO), $0.6 \mu \mathrm{L}$ $(0.3 \mu M)$ of specific primers (12SBT-REV), and $2 \mu \mathrm{L}$ $(100 \mathrm{ng})$ of the template DNA; DNase/DNA-free water (CWBIO, China) was added to the reactions up to 20 $\mu \mathrm{L}$. The PCR products were detected with $1 \%$ agarose gel electrophoresis at $100 \mathrm{~V}$ for $40 \mathrm{~min}$ and photographed under UV light. The fluorescence intensity was measured using image analysis software (Quantity One, Bio-Rad, Hercules, CA).

\section{Quantitative Detection of Cow Milk in Goat Milk Powders}

PCR Conditions. The optimized real-time PCR of primer 12SBT-REV was performed under standard 3 -step thermal cycling conditions: $95^{\circ} \mathrm{C}$ for $10 \mathrm{~min}$ followed by 40 cycles of $94^{\circ} \mathrm{C}$ for $30 \mathrm{~s}, 60^{\circ} \mathrm{C}$ annealing for $60 \mathrm{~s}$, and $72^{\circ} \mathrm{C}$ for $60 \mathrm{~s}$ using a real-time PCR System (Thermo Fisher Scientific Inc.). A $10-\mu \mathrm{L}$ singleplex reaction was prepared comprising $5 \mu \mathrm{L}$ of $2 \times$ Ultal SYBR Mixture (CWBIO), assay-specific primers at $0.3 \mu M$, and $1 \mu \mathrm{L}$ of the template DNA added to each reaction; DNase/DNA-free water (CWBIO) was added to the reactions up to $10 \mu \mathrm{L}$.

Amplification Efficiency and Limit of Detection. The amplification efficiency and limit of detection (LOD) of the 12SBT-REV assay were carried out by analysis of 10-fold diluted DNA solutions (ranging from $1: 1$ to $1: 10,000$, corresponding to a DNA concentration of $50 \mathrm{ng} / \mu \mathrm{L}$ to $5 \mathrm{pg} / \mu \mathrm{L}$ ) extracted from cow milk powder used in real-time PCR with SYBR Green dye (CWBIO). Three replicates of each dilution were performed to construct a standard curve by plotting the cycle threshold $(\mathbf{C t})$ values of real-time PCR analysis against the logarithm of the DNA concentration. The amplification efficiency (E) was calculated from the slope of the standard curve using the following equation: $\mathrm{E}(\%)=\left[10^{(-1 / \text { slope })}-1\right] \times 100$.

Preparation of Quantitative Calibration Curve. The source of the calibrants was the 100\% (wt/ wt) cow milk powder and goat milk powder, which were controlled by admixtures compromising $0.1,0.5,1,5$, 10,30 , and $50 \%$ (wt/wt) cow milk powder in goat milk powder. The DNA was isolated from these calibrants according to the method described above and normalized to $50 \mathrm{ng} / \mu \mathrm{L}$ because of the different DNA yields. These standard DNA templates were then assayed for specific primer 12SBT-REV to construct the laboratory calibration curve for spiked model. A quantitative calibration curve was generated by plotting the logarithm of the percentage of cow milk powder (x-axis) versus mean $\mathrm{Ct}$ value (y-axis) obtained from real-time PCR system for each of the 7 standards used in the calibrant set. Independent simple linear regression curves were fitted to the 12SBT-REV assay calibrant data sets to determine the equation of the straight line $(\mathrm{y}=\mathrm{mx}+$ c) and coefficient of determination $\left(\mathrm{R}^{2}\right)$, where $\mathrm{x}$ was $\log$ (percentage of intentionally added adulterant) and $\mathrm{y}$ was mean $\mathrm{Ct}$ value obtained from the real-time PCR system (Fuchs et al., 2012). Minimum performance criteria were applied to calibration curve $\left(\mathrm{R}^{2}>0.99\right)$, otherwise the experiment was unreliable (Nixon et al., 2015).

Method Validation. To carry out the validation of the real-time PCR technique developed in this work, reliability and repeatability were investigated. The reliability of the real-time PCR method was investigated by repeatedly $(\mathrm{n}=10)$ analyzing DNA extracts from model goat milk powder spiked with $0.1,0.5$, or $1.0 \%$ cow milk powder. The trueness and precision were the important performances of the methodology and analyzed by estimating the relative bias and coefficient variation. In addition, a 1 -sample $t$-test was used to measure the significant differences between each actual percentage of cow milk powder in goat milk powder and the estimated values. To determine the repeatability of the method, serially diluted DNA extracts (50 ng/ $\mu \mathrm{L}$ diluted 1:10, 1:100, 1:500, and 1:5,000) were analyzed on 3 following days in 3 -fold determination. The relative standard deviation (RSD) of $\mathrm{Ct}$ values were analyzed and used to reflect the interday repeatability of the real-time PCR.

\section{RESULTS AND DISCUSSION}

\section{Quality of DNA Extracted from Milk Powders}

DNA Yield and Purity. Determination of DNA concentration and purity is important for downstream applications, such as PCR and multiplex PCR (Boesenberg-Smith et al., 2012). The concentration and purity vary by the extraction method, as well as by the DNA quantification method used. Concerning the DNA concentration in all milk powder samples, high concentrations were observed in the range of 113 to $212 \mathrm{ng} / \mu \mathrm{L}$ (corresponding to a DNA yields of 2.8 to $5.3 \mu \mathrm{g} / \mathrm{g}$ of milk powder), which was higher than previous experiments with raw milk samples (Liu et al., 2014), but had a purity ratio $\left(A_{260} / A_{280}\right.$; absorbance at 260 and 280 $\mathrm{nm}$ ) of about 1.3 to 1.4, lower than the 1.8 expected for pure DNA samples (Sambrook et al., 1989). The high 
yield for milk powder we observed might be related to the high temperature applied in the heating process. As noted by Meng et al. (2016), high temperature contributes to a greater cell membrane permeability, meaning more DNA will be released from the individual somatic cells. However, lower DNA purity of the samples was found because heat-treated milk powder present a high amount of protein, especially denatured protein, which is hardly isolated from and may co-precipitate with genomic DNA. Although the purity ratio obtained from all samples was about 1.3 to 1.4 in the present work, it was sufficient to extract a satisfactory amount of DNA for sample identification by PCR analysis.

DNA Integrity. Integrity of DNA is also an important parameter of DNA quality that could directly reflect the length of fragment we obtained; a longer fragment may have been helpful for PCR amplification, as it contains more of the desired amplification regions. This parameter was used for evaluating the quality of DNA extracted from raw milk in a previous study (Liu et al., 2014; Pokorska et al., 2016). In the current study, DNA was extracted from cow milk powder $(\mathrm{n}=20)$ and goat milk powder $(\mathrm{n}=20)$. The integrity of total DNA extracted from ovine milk powder all showed a positive result, whereas 4 samples of bovine milk powder produced a negative result, which may be related to individual differences in samples. Representative agarose gel electrophoresis analysis (Figure 1) showed that the obtained bands were clear and consistent, with good integrity and no smearing or diffusion. This indicated that a sufficient amount of quality DNA was isolated through the method we developed in the present study. In addition, the integrity of mitochondrial DNA extracted from both ovine and bovine milk powder all showed a positive result, indicating that although no intact DNA fragment was obtained, these samples still could be used for PCR amplification, as the desired amplification regions still existed but were not visible. The representative results of PCR amplification (Figure 2) also showed that the obtained bands were clear and single; no nonspecific products or dimmer fragments were found. Therefore, high-quality mitochondrial DNA could be also isolated from milk powders, which suggests the extracted DNA might be applied to species identification.

Summary. High-quality DNA is relatively difficult to extract from milk powder compared with raw milk, because milk powder is associated with high-temperature treatments during processing. Musto et al. (2014) proved that heat treatment has an effect on the quality of DNA extracted from food material, as it could shorten the length of both mitochondrial and nuclear DNA fragments. However, we found DNA extracted from milk powder that experienced a high-temperature

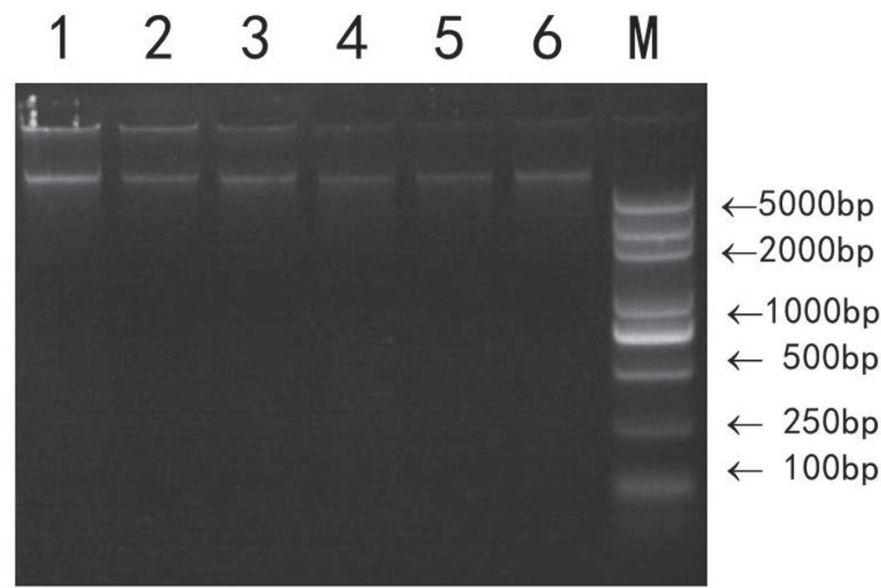

Figure 1. Representative results from agarose gel electrophoresis analysis of DNA from 6 random milk powder samples. Lanes 1, 2, $3=$ ovine DNA; lanes $4,5,6=$ bovine DNA; $\mathrm{M}=$ molecular weight marker (5,000-bp DNA ladder).

treatment to have a good yield, purity, and integrity. Thus, the DNA extraction method we described is suitable for milk powder.

\section{Results of Qualitative Detection}

The simplex PCR assay was optimized for discriminating cow milk in goat milk powder matrices to detect adulteration of goat milk powder with cow milk powder. The PCR tests used in this screening were very sensitive, specific, and reproducible (Figure 3). Simplex PCR tests showed a minimum LOD of $0.1 \%$ (wt/wt), indicating that the analytical assay unequivocally detected cow milk compositions, even when it was present in small amounts. In addition, the fluorescence intensity of bonds we obtained showed an enhanced trend with an increasing proportion of adulteration. Thus,

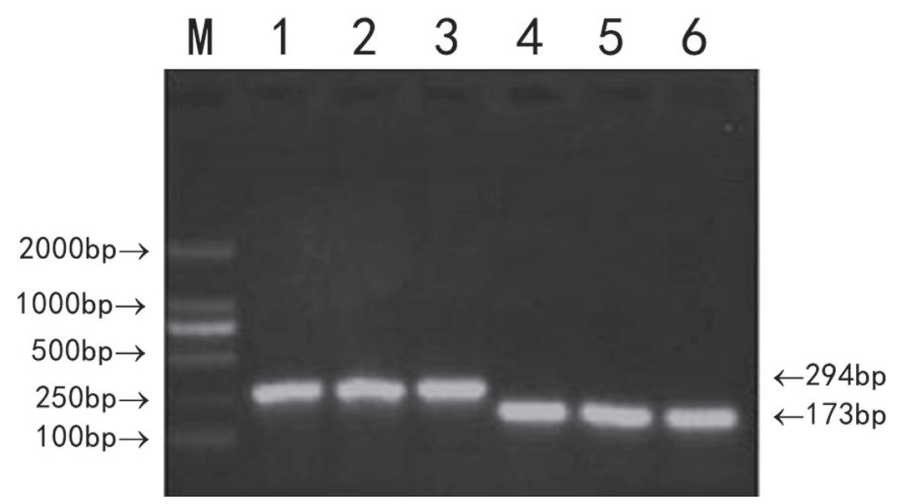

Figure 2. Representative results from agarose gel electrophoresis analysis of PCR products. Lanes $1,2,3=$ ovine ATP- 6 gene; lanes 4, 5, $6=$ bovine $C y t b$ gene; $\mathrm{M}=$ molecular weight marker $(2,000$-bp DNA ladder). 
our results might be applied to quantitative analysis by establishing a regression equation between the proportion of adulteration and fluorescence intensity of bond; however, this was not studied in the current experiment. Mafra et al. (2007) used duplex PCR for quantification of cow and goat milk in cheese in the range of 1 to $60 \%$ with 30 cycles by means of a normalized standard curve that was successfully applied to known cheeses, confirming that conventional PCR has the potential to be applied to quantitative analysis.

Conventional PCR has many advantages, such as low LOD, strong specificity, and high sensitivity. More importantly, it costs less and requires lower experimental conditions than real-time PCR; thus, it could be used in most laboratories. Our study did not include a quantitative analysis for DNA adulteration of goat milk powders based on conventional PCR. As adulteration is prohibited in most countries under legislation regulating dairy products, it was not necessary to use PCR assay as a qualitative tool for the presence or absence of adulterant cow milk compositions (Golinelli et al., 2014). If necessary, quantitative determination of adulteration with real-time PCR should be preferred, because conventional PCR was semiquantitative and would be affected by many factors to produce a false positive.

\section{Results of Quantitative Detection}

Sensitivity of SYBR Green PCR Systems. Ten-fold serially diluted DNA extracts from cow milk powder were analyzed to determine the amplification efficiency and LOD of the assay based on primer pair $12 S B T-R E V$ in real-time PCR. Plotting the Ct values obtained in the analysis of serially diluted cow milk powder DNA extracts against the logarithm of the initial DNA amount resulted in linear standard curves in the range from $50 \mathrm{ng}$ to $5 \mathrm{pg}$ of DNA (Figure 4). The slope of the standard curve was -3.91 , indicating amplification efficiency of $80.2 \%$. Milk powder that experienced heat treatment gave a lower slope and amplification efficiency, as we expected. The obtained data for coefficient of determination $\left(\mathrm{R}^{2}=0.9991\right)$ and $\mathrm{LOD}$ (5 pg) of the standard curve may be acceptable according to the literature (Vaerman et al., 2004; Arlorio et al., 2007). These results showed that SYBR Green PCR system we described had a great sensitivity and could be used for further trials.

Establishment of Quantitative Calibration Curve. The $\mathrm{Ct}$ values obtained in real-time PCR analysis of the spiked samples (intentionally adulterated) were used to build the laboratory adulteration calibration curve. Plotting the $\mathrm{Ct}$ values obtained in real-time PCR analysis against the logarithm of the

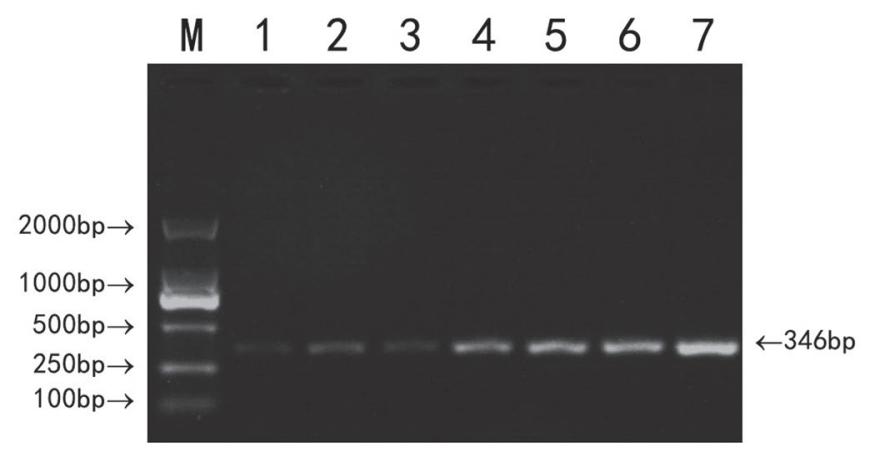

Figure 3. Representative results from agarose gel electrophoresis analysis of PCR detection. Lanes $1,2,3,4,5,6$, and $7=$ mixture of goat and cow milk powders containing $0.1,0.5,1,5,10,30$, and $50 \%$ cow milk composition, respectively; $\mathrm{M}=$ molecular weight marker (2,000-bp DNA ladder).

spike level of the model milk powder mixture resulted in the quantitative calibration curves shown in Figure 5. It showed a good coefficient of determination $\left(\mathrm{R}^{2}=\right.$ 0.9984 ) in the range of 0.1 to $50 \%$ and could be used to accurately reflect the percentage of cow milk powder in goat milk powder. Although some studies have reported that heat treatment may lead to a strongly reduced average fragment length, which can lead to lower coefficient of determination and slope values (Doveri and Lee, 2007), the coefficient of determination and slope values obtained in the present work were quite satisfactory.

Method Validation. Due to the importance of the $<1 \%$ (wt/wt) level for food labeling purposes, the reliability of the real-time PCR method were evaluated by repeatedly $(\mathrm{n}=10)$ analyzing DNA extracts from model goat milk powder spiked with $0.1,0.5$, or $1 \%$ cow milk powder; the results were summarized in Table 2. At the 3 spike levels, all replicates yielded positive PCR results and relative quantitative analyses showed good compa-

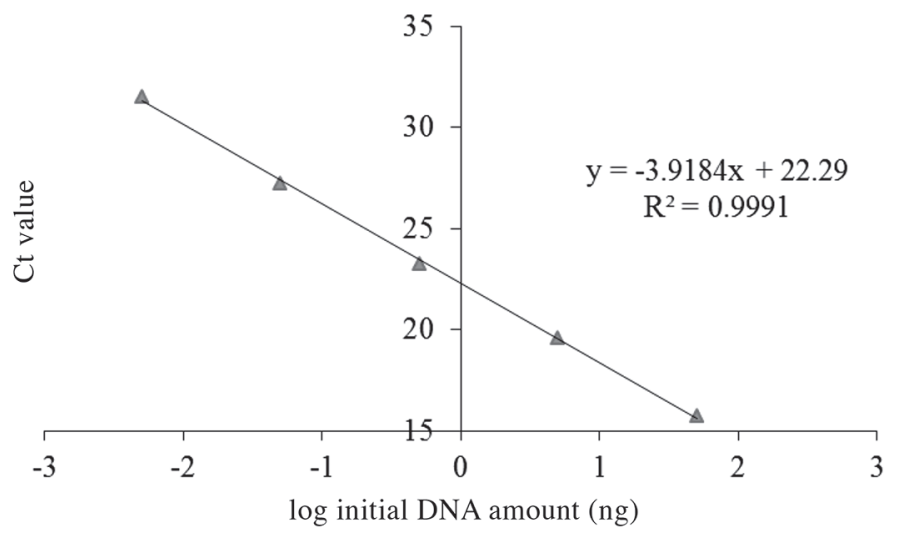

Figure 4. Standard curve obtained by analyzing serially diluted DNA extracts from bovine milk powders. $\mathrm{Ct}=$ cycle threshold. 
Table 2. Reliability of the real-time PCR method with DNA extracts from model milk powder near the limit of detection

\begin{tabular}{lcccc}
\hline $\begin{array}{l}\text { Spike } \\
\text { level }(\%)\end{array}$ & $\begin{array}{c}\text { Mean } \\
\text { estimated }^{1}(\%)\end{array}$ & $\begin{array}{c}\text { Bias } \\
\text { (trueness; } \%)\end{array}$ & $\begin{array}{c}\text { CV } \\
\text { (precision; \%) }\end{array}$ & $\begin{array}{c}P \text {-value } \\
(t \text {-test) }\end{array}$ \\
\hline 0.1 & 0.15 & +27.3 & 25.0 & 0.024 \\
0.5 & 0.51 & +2.1 & 28.8 & 0.824 \\
1.0 & 0.98 & -1.9 & 12.5 & 0.638 \\
\hline
\end{tabular}

${ }^{1}$ Values are the mean of replicate assays $(n=10)$.

rability between the estimated and actual percentage of bovine DNA levels. The trueness estimates showed that the most bias was associated with the $0.1 \%$ spiked level, which was to be expected given the low concentration of the target analyte present in the sample. The coefficients of variation varied between 12.5 and $28.8 \%$, with poor levels of precision generally exhibited with the lower-level gravimetric materials. The trueness was much improved at the 0.5 and $1 \%$ (wt/wt) levels, but the precision associated with the method, as captured by the coefficient of variation, was higher than $10 \%$ but never greater than $30 \%$. Our results may be acceptable, because real-time PCR-based detection methods often display an RSD of 30\% (Hübner et al., 2001), and some reports have also shown a high coefficient of variation similar to our results (Eugster et al., 2008; Nixon et al., 2015). According to the results of our 1-sample $t$ test, the estimated percentages for goat milk powder containing 0.5 and $1 \%$ of cow milk powder were not significantly different $(P>0.05)$ but there was a significant difference between actual and estimated value with $0.1 \%$ cow milk powder $(P<0.05)$, meaning that the estimation of cow milk composition in goat milk powder was not accurate for $0.1 \%$ cow milk powder.

To determine the repeatability of the method, interday repeatability of the real-time PCR assay was investigated by analyzing serially diluted cow milk powder

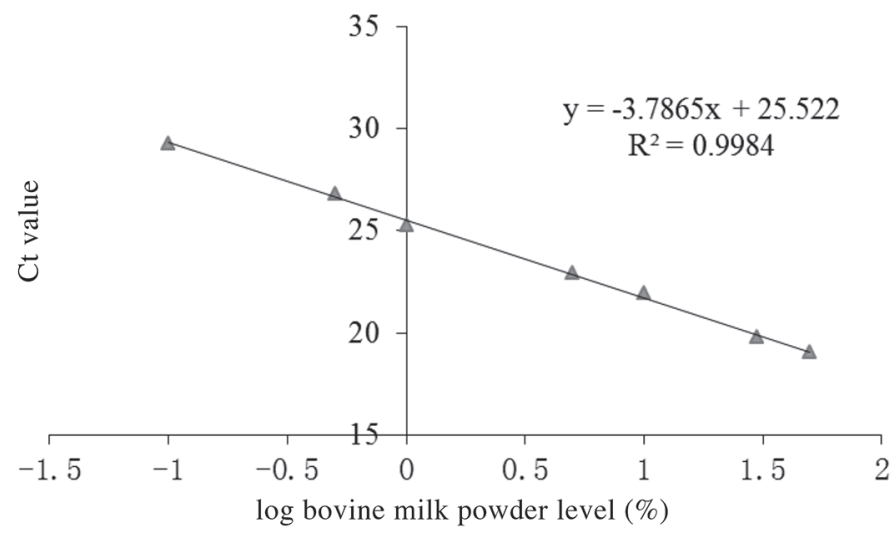

Figure 5. Standard curve obtained by analysis of DNA extracts from model milk powders. $\mathrm{Ct}=$ cycle threshold.
DNA extracts $(50 \mathrm{ng} / \mu \mathrm{L}$, diluted 1:10, 1:100, 1:500, and $1: 5,000$ ) on 3 consecutive days (Table 3 ). The RSD were never higher than $2 \%$, thus demonstrating the high repeatability of the method down to the dilution factor 1:5,000, corresponding to a DNA concentration of $10 \mathrm{pg} / \mu \mathrm{L}$.

The applicability of the real-time PCR method on commercial goat milk powder was not a focus here, because the focus of the current study was not to validate a set of commercial goat milk but to characterize the performance of the methodology. Further work should develop a set of appropriate samples for follow-on interlaboratory method-validation activities.

\section{CONCLUSIONS}

Extraction of DNA is one of the most important factors that could affect the successful implementation of PCR-based methods. Thus, we established a novel DNA extraction method from milk powder, which has been used for PCR investigation of milk powder. Conventional PCR and real-time PCR were developed for detection and quantification of cow milk compositions as adulterants in commercial ground goat milk powders, respectively. The study also suggests that a rational choice of PCR method should be based on the material costs and laboratory requirements. The method we described here may be a useful tool for food inspection services to trace the species origin of dairy products. However, to be used by government agencies as a tool for monitoring milk powder adulteration, the method presented here needs to be thoroughly validated for accurate quantification and additional primers need to be developed for identification of different types of potential adulterants, such as soybean and others.

\section{ACKNOWLEDGMENTS}

This work was supported by the China postdoctoral science foundation (2015M570811), the national twelfth "Five Year" science and technology support project (2012BAD12B07), the fundamental research funds for the central universities of China (GK201502008), and 
Table 3. Repeatability of the real-time PCR assay; experiments were performed with serially diluted bovine milk powder extracts in 3 -fold determination on 3 consecutive days

\begin{tabular}{|c|c|c|c|c|c|}
\hline \multirow{2}{*}{$\begin{array}{l}\text { Dilution } \\
\text { factor }\end{array}$} & \multirow{2}{*}{$\begin{array}{l}\text { DNA concentration } \\
(\mathrm{pg} / \mu \mathrm{L})\end{array}$} & \multicolumn{3}{|c|}{ Mean cycle threshold values } & \multirow{2}{*}{$\begin{array}{l}\text { Relative } \\
\text { SD (\%) }\end{array}$} \\
\hline & & d 1 & $\mathrm{~d} 2$ & d 3 & \\
\hline $1: 10$ & 5,000 & 19.28 & 19.07 & 19.08 & 0.62 \\
\hline $1: 100$ & 500 & 23.11 & 22.65 & 22.76 & 1.05 \\
\hline $1: 500$ & 100 & 25.75 & 25.58 & 26.11 & 1.05 \\
\hline $1: 5000$ & 10 & 29.91 & 29.61 & 29.41 & 0.85 \\
\hline
\end{tabular}

the college students' innovative entrepreneurial training plan of Shaanxi Normal University (CX16034).

\section{REFERENCES}

Arlorio, M., E. Cereti, J. D. Coisson, F. Travaglia, and A. Martelli. 2007. Detection of hazelnut (Corylus spp.) in processed foods using real-time PCR. Food Contr. 18:140-148.

Boesenberg-Smith, K. A., M. M. Pessarakli, and D. M. Wolk. 2012. Assessment of DNA yield and purity: an overlooked detail of PCR troubleshooting. Clin. Microbiol. Newsl. 34:1-6.

Doveri, S., and D. Lee. 2007. Development of sensitive crop-specific polymerase chain reaction assays using 5S DNA: Applications in food traceability. J. Agric. Food Chem. 55:4640-4644.

Enne, G., D. Elez, F. Fondrini, I. Bonizzi, M. Feligini, and R. Aleandri 2005. High-performance liquid chromatography of governing liquid to detect illegal bovine milk's addition in water buffalo mozzarella: Comparison with results from raw milk and cheese matrix. J. Chromatogr. A 1094:169-174.

Eugster, A., J. Ruf, J. Rentsch, P. Hübner, and R. Köppel. 2008. Quantification of beef and pork fraction in sausages by real-time PCR analysis: Results of an interlaboratory trial. Eur. Food Res. Technol. 227:17-20.

Fuchs, M., M. Cichna-Markl, and R. Hochegger. 2012. Development and validation of a novel real-time PCR method for the detection of celery (Apium graveolens) in food. Food Chem. 130:189-195.

Golinelli, L. P., A. C. Carvalho, R. S. Casaes, C. S. C. Lopes, R. Deliza, V. M. F. Paschoalin, and J. T. Silva. 2014. Sensory analysis and species-specific PCR detect bovine milk adulteration of frescal (fresh) goat cheese. J. Dairy Sci. 97:6693-6699.

Hübner, P., H. U. Waiblinger, K. Pietsch, and P. Brodmann. 2001. Validation of PCR methods for quantitation of genetically modified plants in food. J. AOAC Int. 84:1855-1864.

Hutu, I., O. Boldura, S. Popescu, C. Balta, C. Chis, and C. Mircu. 2013. A multiplex PCR approach to the quantification of cow milk in goat products. Curr. Opin. Biotechnol. 24:S95.

Jung, Y. K., D. Y. Jhon, K. H. Kim, and Y. H. Hong. 2011. Quantitative detection of cow milk in goat milk mixtures by real-time PCR. Korean J. Food Sci. Anim. Resour. 31:827-833.

Kotowicz, M., E. Adamczyk, and J. Bania. 2007. Application of a duplex-PCR for detection of cows' milk in goats' milk. Ann. Agric. Environ. Med. 14:215-218.

Liu, G., Y. Li, J. Cao, D. Ren, D. Yuan, and L. Zhang. 2012. Changes of microbiological and physicochemical properties in Chinese infant formula caused by high heat treatment applied on concentrated milk. Dairy Sci. Technol. 92:719-733.

Liu, Y. F., J. L. Gao, Y. F. Yang, T. Ku, and L. S. Zan. 2014. Novel extraction method of genomic DNA suitable for long-fragment amplification from small amounts of milk. J. Dairy Sci. 97:6804-6809.

López-Calleja, I., I. G. Alonso, V. Fajardo, M. A. Rodríguez, P. E. Hernández, T. García, and R. Martín. 2005. PCR detection of cows' milk in water buffalo milk and mozzarella cheese. Int. Dairy J. 15:1122-1129.

López-Calleja, I. M., I. Gonzalez, V. Fajardo, P. E. Hernandez, T. García, and R. Martín. 2007. Application of an indirect ELISA and a PCR technique for detection of cows' milk in sheep's and goats' milk cheeses. Int. Dairy J. 17:87-93.

Lopparelli, R. M., B. Cardazzo, S. Balzan, V. Giaccone, and E. Novelli. 2007. Real-time TaqMan polymerase chain reaction detection and quantification of cow DNA in pure water buffalo mozzarella cheese: Method validation and its application on commercial samples. J. Agric. Food Chem. 55:3429-3434.

Madani, M., S. A. Subbotin, and M. Moens. 2005. Quantitative detection of the potato cyst nematode, Globodera pallida, and the beet cyst nematode, Heterodera schachtii, using real-time PCR with SYBR green I dye. Mol. Cell. Probes 19:81-86.

Mafra, I., A. Roxo, I. M. Ferreira, and M. B. P. Oliveira. 2007. A duplex polymerase chain reaction for the quantitative detection of cows' milk in goats' milk cheese. Int. Dairy J. 17:1132-1138.

Mayer, H. K. 2005. Milk species identification in cheese varieties using electrophoretic, chromatographic and PCR techniques. Int. Dairy J. 15:595-604.

Meng, J., Y. Gong, P. Qian, J. Y. Yu, X. J. Zhang, and R. R. Lu. 2016. Combined effects of ultra-high hydrostatic pressure and mild heat on the inactivation of Bacillus subtilis. LWT Food Sci. Technol. 68:59-66.

Mininni, A. N., C. Pellizzari, B. Cardazzo, L. Carraro, S. Balzan, and E. Novelli. 2009. Evaluation of real-time PCR assays for detection and quantification of fraudulent addition of bovine milk to caprine and ovine milk for cheese manufacture. Int. Dairy J. 19:617-623.

Musto, M., D. Faraone, F. Cellini, and E. Musto. 2014. Changes of DNA quality and meat physicochemical properties in bovine supraspinatus muscle during microwave heating. J. Sci. Food Agric. 94:785-791.

Nixon, G. J., T. M. Wilkes, and M. J. Burns. 2015. Development of a real-time PCR approach for the relative quantitation of horse DNA. Anal. Methods 7:8590-8596.

Pokorska, J., D. Kułaj, M. Dusza, J. Żychlińska-Buczek, and J. Makulska. 2016. New rapid method of DNA isolation from milk somatic cells. Anim. Biotechnol. 27:113-117.

Raynal-Ljutovac, K., G. Lagriffoul, P. Paccard, I. Guillet, and Y. Chilliard. 2008. Composition of goat and sheep milk products: An update. Small Rumin. Res. 79:57-72.

Sambrook, J., E. F. Fritsch, and T. Maniatis. 1989. Molecular Cloning. Cold Spring Harbor Laboratory Press, Cold Spring Harbor, NY.

Vaerman, J. L., P. Saussoy, and I. Ingargiola. 2004. Evaluation of real-time PCR data. J. Biol. Regul. Homeost. Agents 18:212-214.

Volk, H., S. Piskernik, M. Kurinčič, A. Klančnik, N. Toplak, and B. Jeršek. 2014. Evaluation of different methods for DNA extraction from milk. J. Food Nutr. Res. 53:97-104.

Zachar, P., M. Soltés, R. Kasarda, J. Novotný, M. Novikmecová, and D. Marcinčáková. 2011. Analytical methods for the species identification of milk and milk products. Mljekarstvo 61:199-207. 